ISSN: $1576-0162$

DOI: http://dx.doi.org/10.33776/rem.v0i55.3838

\title{
Taxation of Tourism Activities: A Review of the Top 50 TOURISM DESTINATIONS
}

TRIBUTACIÓN DE ACTIVIDADES TURISTICAS: REVISIÓN DE LOS 50 PRINCIPALES DESTINOS TURISTICOS

José Luis Durān-Román

Universidad de Jaén jduran@ujaen.es

Pablo Juan Cárdenas-García Laboratorio de Análisis e Innovación Turística (LAInnTUR)

Universidad de Jaén pcgarcia@ujaen.es

Juan Ignacio Pulido-Fernández Laboratorio de Análisis e Innovación Turística (LAInnTUR)

Universidad de Jaén jipulido@ujaen.es

Recibido: octubre de 2019; aceptado: enero de 2020

\begin{abstract}
Public authorities have played a key role in tourism competitiveness, as this agent is obliged to provide certain infrastructure and services. This has led to incurring certain additional costs that may be financed by contributions from the implementation of fiscal instruments. The objective of the present work is to identify the tourist taxes implemented in the 50 main world tourist destinations. To do this, different official, national and international sources have been consulted. Tourist taxes have been identified in 49 of the 50 main tourist destinations; and have been configured, therefore, as an effective instrument for obtaining the necessary financing.
\end{abstract}

Keywords: Tourism destination; tourism tax; public policy; destination management; financing. 
RESUMEN

Los poderes públicos han desempeñado un papel clave en la competitividad turística, al recaer sobre este agente la obligación de proporcionar determinadas infraestructuras y servicios. Ello ha provocado incurrir en determinados costes adicionales, ante lo cual, la implantación de instrumentos fiscales puede contribuir a obtener la financiación necesaria. El objetivo del presente trabajo es identificar los tributos de carácter turístico implantados en los cincuenta principales destinos turísticos mundiales. Para ello, se han consultado distintas fuentes oficiales, nacionales e internacionales. Se han identificado tributos de carácter turístico en 49 de los 50 principales destinos turísticos; configurándose, por tanto, como un instrumento eficaz para obtener la financiaciōn necesaria.

Palabras clave: destino turístico; tributaciōn turística; políticas públicas; gestiōn del destino; financiaciōn.

Clasificación JEL / JEL classification: H71; L83; H59; H69; H74; R50. 


\section{INTRODUCTION}

There is no doubt as to the economic potential of tourism in the areas considered to be top global tourism destinations. The importance of tourism on economic growth and, in some cases, also on the improvement of economic development (Cárdenas et al., 2015; UNWTO, 2005; WTTC, 2005), and its repercussion, therefore, on the welfare of the population (Chen and ChiouWei, 2009; Crouch and Ritchie 1999; Dwyer and Kim 2003; Holzner, 2011; Kim et al., 2006; Ma and Hassink, 2013; Tang and Tan, 2015; Tugcu, 2014), has led numerous countries to promote an increase in their incoming tourism flows, through the allocation of public resources with the aim of improving their competitive position compared to other destinations (Webster and Ivanov, 2014).

In this search for tourism competitiveness, the Public Administration plays a key role (Kerr, 2003; Page and Connell, 2006). The administration is responsible for the provision of specific goods and services (Hall, 2000; Okumus et al., 2012; Page, 2009; Ritchie and Crouch, 2003) both for the tourist, ensuring that the tourist enjoys his/her experience, as well as for the tourism destination itself, making it more attractive in the tourism markets (Pulido and Cárdenas, 2012). Therefore, the Public Administration is obligated to provide certain public goods and services, leading to certain costs being incurred in its public budgets, which in most cases does not bring about any simultaneous income generation with which these may be financed.

Tourism taxation has been configured, on numerous occasions, as an instrument for dealing with the problems derived from tourism development (Gooroochurn and Sinclair, 2003), through the establishment of specific taxes (Cetin et al., 2017) destined directly for the activity (Litvin et al., 2006) and, therefore, to the improvement of the tourist experience (Cetin et al., 2017). A large number of governments have shown themselves in favor of the implementation of these taxes. Since, in addition to obtaining a large amount of public resources (Ponjan and Thirawat, 2016), from a political point of view, the establishment of a tax linked to tourism activity implies a lower risk for national governments, since the obligation for payment falls on international tourists (Jensen and Wanhill, 2002), without the right to vote.

However, the controversy regarding the establishment of tourist taxes is not something new since, from a theoretical point of view, the establishment of this type of tax entails a loss of competitiveness of the destination in the 
international tourist markets (Myers et al., 1997), as a consequence of the increase in prices and, therefore, a drop in number of visitors. In this sense, there are various studies (Durbarry and Sinclair, 2001; Hiemstra and Ismail, 1992; Ihalanayake and Divisekera, 2006; Jensen and Wanhill, 2002) in which the direct correlation between the tax increase and the weakening of tourism demand is shown. Not taking into account any possible reprisals between governments of different countries, deriving from the establishment of tourist taxes ${ }^{1}$.

The objective of this work is to identify how the governments of the 50 main tourist destinations worldwide have solved this problem. To achieve this objective, a revision, analysis and characterization was carried out for the touristic taxes implemented in these tourism destinations, allowing us to determine the most frequently used taxes in these countries, as well as the essential characteristics of each of them. For this, official sources will be consulted, both international (IATA, OECD, UNWTO) and national (governmental, ministerial and institutional), in each of the 50 main tourist destinations.

\section{THEORETICAL FRAMEWORK}

\subsection{TOURIST TAXATION}

The tourist activity does not develop in an isolated way. It is the result of multiple interactions in a specific geographical space between tourists and receiving population, which causes a series of economic, social, environmental (Mclntosh and Goeldner, 1990) and personal impacts - that include both physical and psychological factors (Besculides et al., 2002).

Tourism taxation has been configured, on numerous occasions, as an instrument for dealing with the problems arising from tourism development (Gooroochurn and Sinclair, 2003); it being an activity taxed since its inception to increase revenues, offset the costs derived from the provision of goods and services of a public nature and correct market failures or negative externalities caused by tourism activity (Gago et al., 2009; Gooroochurn and Sinclair, 2005; Hughes, 1981; Ponjan and Thirawat, 2016; Ryan, 2002;). In addition, it can also be used to achieve other purposes, such as job creation, economic development promotion, environmental protection, destination promotion, etc. (OECD, 2014). Therefore, and based on the previous, the establishment of tourism taxation acts as a corrective mechanism and substitute for a cost of public goods and services that are consumed by tourists (Pastor, 2016), with the objective of re-establishing economic efficiency (Clarke and $\mathrm{Ng}, 1993$ ).

\footnotetext{
${ }^{1}$ In this regard, Gooroochum and Sinclair (2003) point out that Kenya and Tanzania placed visa obligations on British citizens as a result of the UK establishing a visa fee for their respective citizens.
} 
Therefore, tourism taxation becomes a tool through which to distribute the costs associated with tourism activity, through the establishment of specific taxes (Cetin et al., 2017) destined directly to the activity (Litvin et al., 2006), which pursue an extra-fiscal purpose, and whose objective is to improve the product (Cetin et al., 2017) and hence the tourist experience. In this sense, the OECD (2014:76), defined tourism taxation as "the indirect taxes, taxes and tributes that mainly affect the activities related to tourism"; and it is considered to be one of the main elements by which it is possible to "contribute to the obtaining of taxation income, financing the protection of the environment and public investment and the development of infrastructures to improve the management of the tourism impact in sensitive areas". So tourism taxation plays a double role: influencing the competitiveness of the destination and financing the costs derived from tourism activity.

\subsection{TOURISM COMPETITIVENESS}

Since the middle of the last century, there has been an increase in tourist activity, mainly due to the fact that travel has become an increasingly accessible commodity for the population in general (Sánchez, 2012), and this activity is now one of the main activities and of faster growth in the current global economy (UNCTAD, 2013). The public administrations of the receiving countries obtain major quantities of public resources that are directly derived from the expansion of tourism activity, with this income potentially representing between $10 \%$ and $25 \%$ of the total collected from taxation (UNWTO, 1998), reaching 50\% -as in the case of the Bahamas- (Gooroochurn and Sinclair, 2005) or even almost $100 \%$ in certain economies -as in the case of the Maldives (McAleer et al., 2005).

The competitiveness of tourism has emerged, since the nineties, as one of the main research topics, mainly due to the increase and diversification of tourist destinations, the progressive reduction in traditional destinations of the market share in relation to the number of international arrivals of tourists and, therefore, the increase in rivalry between destinations (García and Siles, 2015). Consequently, there is a need to examine which new factors and strategies guarantee their competitiveness (Lillo et al., 2007), and hence the improvement of this competitiveness has become one of the main objectives of the tourist policy of the said destinations (Diaz, 2006) and one of the key factors for its success (Buhalis, 2000; Chen, 2008; Dwyer and Kim, 2003; Enright and Newton, 2004; Gooroochurn and Sugiyarto, 2005; Mangion et al., 2005; Nasr, 2016; Webster and Ivanov, 2014).

A large number of determinants of tourism competitiveness depend directly on the provision of goods and services by the public sector, thus the public sector plays a key role (Kerr, 2003; Page and Connell, 2006), as it is responsible for providing a range of goods and services. To do this, it must have basic infrastructures and guarantee a number of services (Hall, 2000; Page, 2009; Ritchie and Crouch, 2003) -destination promotion and 
marketing, security, cleaning, environmental preservation, conservation of the cultural heritage, etc. - to provide an optimal experience for tourists. In this sense, Murphy et al. (2000) conclude that both environmental conditions and infrastructure have a strong impact on the perceptions of tourists, which in turn has an impact on the competitiveness evaluation of a destination.

\subsection{TOURISM FINANCING}

Therefore, in light of the above, for a tourist destination to be successful, the intervention of public authorities is necessary, stimulating the creation of goods and services, adding value to the destination, with the objective of remaining competitive in the market (Molina et al., 2014). For this purpose, the destination needs to be provided with public funds, in order to improve their competitiveness and attract a greater number of tourists (Jovanovic et al., 2015). In this sense, Costa (2003) highlights the concern about the successive budget deficits incurred by tourist destinations as a result of the assumption that the expenses derived from the provision of tourism goods and services exceed the income generated by tourism, causing a decrease in the quality of the provision of local public services and damaging the welfare of the resident population.

The provision of these public services, directly linked to the tourism activity, implicates the incurring of a series of additional costs which, in most cases, do not result in the creation of simultaneous income with which they may be financed (Secretary General of Tourism, 2008).

According to Puig (2007), the administrations greatly influenced by tourism have revealed financing problems, for which some tax instruments can play the role of helping to obtain the necessary financing to address public policies. In addition, from an economic perspective, designing a tax system on tourism activity for which the agents involved in the tourism market are responsible seems fair. These agents would be responsible for financing certain public goods and services that are provided by the public administration (Clarke and $\mathrm{Ng}, 1$ 993; Gago and Labandeira, 2001). Bokobo (1999: 243) underlines that for "a destination to remain attractive, it needs large investments in goods, services and environment conservation, which are mostly obtained through taxes from the residents".

The distinct public administrations should devote this income to the creation of a highly competitive tourism environment, requiring differentiation and positioning strategies by the agents entrusted with the management of the destination, in order to capture a large share of the demand and, thereby increase the income generated by the expansion of the tourism activity in any given tourism destination. In this context, the OECD (2014) has established six distinct categories of tourism taxes (Table 1).

Arrival and departure: Include taxes, tributes and fees that are levied upon the arrival or departure to or from a country. These taxes are levied primarily on individuals, although they may also be levied on operators or crews. 
TABle 1. Tourist taxes CATEgories according to the OECD

\begin{tabular}{|l|l|}
\hline Categories & Tax \\
\hline Arrival and departure & $\begin{array}{l}\text { Requirements and fees associated with the obtaining of visas } \\
\text { Charges for passenger travel, movement, exit, boarding }\end{array}$ \\
\hline Air travel & $\begin{array}{l}\text { Airport taxes (landing tax and wait of aircrafts, aircraft parking tax, } \\
\text { terminal fee) } \\
\text { Security taxes and exit taxes (tax on air transport, tax on air travel and } \\
\text { air passenger rights) }\end{array}$ \\
\hline Hotels and Accommodation & $\begin{array}{l}\text { Lodging taxes } \\
\text { Bed tax } \\
\text { Occupancy tax } \\
\text { Tourism tax }\end{array}$ \\
\hline Taxation types on consumption & $\begin{array}{l}\text { Added value tax } \\
\text { Tax on goods and services }\end{array}$ \\
\hline Environment & \begin{tabular}{l} 
Environmental fees and taxes \\
\hline Incentives
\end{tabular} \\
$\begin{array}{ll}\text { Reductions on income taxes } \\
\text { Reduced corporation taxes } \\
\text { Investment tax credits } \\
\text { Expense incentives and deductions } \\
\text { Exemption of indirect taxes }\end{array}$ \\
\hline
\end{tabular}

Source: Author's own creation from the OECD (2014).

Air travel: Taxes, tributes and fees applied specifically to airline trips with the objective of financing the increase in costs derived from service provision security, passenger services and airport exits - and, in some cases, to promote more respectful environmental behavior.

Hotels and Accommodation: Taxes or tributes levied specifically on hotels and lodging services that tend to be administered on a regional and local level.

Tax rates on consumption: Include both taxes on the added value as well as taxes on goods and services. Tax rates vary from one country to another, and some governments foster the introduction of reduced rates in the consumption of activities related to the tourism activity, mainly hotels and restaurants.

Environment: Environmental taxes, eco-taxes or ecological taxes are taxes of an environmental nature, established by certain governments to protect the environment.

Incentives: Established based on a tax law or regulation that has the objective of alleviating the fiscal load of a certain set of activities.

\section{Methodology}

To achieve the objective of this work, consisting of the identification of the distinct taxes implemented by the top global tourism destinations that levy them on tourism activities -which shall permit us to determine which are the most commonly used taxes, as well as the essential characteristics of each of these- we have conducted a review, analysis and information compilation of international organizations IATA, OECD, UNWTO - and national organizations (governmental, ministerial and institutional). The other sources used are included in the different results annexes. 
Internationally, the IATA - the International Air Transport Associationoffers information with regards to taxes related to air transport. The OECD, both in its Tourism Trends and Policies report (2014) and in its database on environmental policy instruments, compiles a list of certain tourist taxes implemented in its member countries. Finally, both the UNWTO report (Tourism taxation. Striking a fair deal, 1998) and the Forsyth and Dwyer (2002) and Gooroochurn and Sinclair (2005) investigations were used as input to make a first identification of different tourism taxes implemented internationally.

At the national level, and with the input of the taxes identified through the international organizations and authors mentioned above, a search and review of possible tourist taxes was carried out in the 50 main destinations. For this, and through their respective websites, official sources have been analyzed at three different levels: governmental, ministerial (security, interior, foreign affairs, immigration, international cooperation) and institutional (consulates, embassies, air authorities, airports and airlines).

Official sources belong to each of the governments of the fifty main tourism destinations of the world, between the years 2014 and 2017. Said time frame was selected with the goal of obtaining recent information on the implemented taxes. The classification of the countries used was that facilitated by the UNWTO (2016), offering country information based on the number of international tourist arrivals; a variable that is traditionally considered to determine the importance of a country in terms of its capability of generating tourism activity.

TABLE 2. TOP TOURISM DESTINATIONS FOR 2015 (NUMBER OF INTERNATIONAL TOURIST ARRIVALS)

\begin{tabular}{|l|l|r|r|l|r|r|l|r|}
\hline Pos. & \multicolumn{1}{|c|}{ Country } & Arrivals & \multicolumn{1}{|c|}{ Pos. } & \multicolumn{1}{c|}{ Country } & \multicolumn{1}{c|}{ Arrivals } & \multicolumn{1}{c|}{ Pos. } & \multicolumn{1}{c|}{ Country } & Arrivals \\
\hline 1 & France & 84.45 & 18 & Canada & 17.97 & 35 & Belgium & 8.03 \\
\hline 2 & USA & 77.51 & 19 & Poland & 16.72 & 36 & India & 8.02 \\
\hline 3 & Spain & 68.21 & 20 & Netherlands & 15.00 & 37 & Vietnam & 7.94 \\
\hline 4 & China & 56.88 & 21 & Hungary & 14.31 & 38 & Australia & 7.44 \\
\hline 5 & Italy & 22 & Macao & 14.30 & 39 & Brazil & 6.30 \\
\hline 6 & Turkey & 34.47 & 23 & Rep. of Korea & 13.23 & 40 & Argentina & 5.73 \\
\hline 7 & Germany & 24 & Croatia & 12.68 & 41 & Dom. Rep. & 5.60 \\
\hline 8 & United Kin. & 34.43 & 25 & Ukraine & 12.42 & 42 & Philippines & 5.36 \\
\hline 9 & Mexico & 32.09 & 26 & Singapore & 12.05 & 43 & Tunisia & 5.35 \\
\hline 10 & Russian Fed. & 27 & Czech Rep. & 11.14 & 44 & Iran & 5.23 \\
\hline 11 & Thailand & 29.88 & 28 & Taiwan & 10.44 & 45 & Cambodia & 4.77 \\
\hline 12 & Austria & 26.71 & 29 & Indonesia & 10.40 & 46 & Myanmar & 4.68 \\
\hline 13 & Hong-Kong & 26.68 & 30 & Morocco & 10.17 & 47 & Chile & 4.47 \\
\hline 14 & Malaysia & 25.72 & 31 & Portugal & 10.17 & 48 & Albania & 3.78 \\
\hline 15 & Greece & 23.59 & 32 & Switzerland & 9.30 & 49 & Jordan & 3.76 \\
\hline 16 & Japan & 19.73 & 33 & Egypt & 9.13 & 50 & Puerto R. & 3.54 \\
\hline 17 & S. Arabia & 17.99 & 34 & South Africa & 8.90 & & & \\
\hline
\end{tabular}

Source: Author's creation based on the UNWTO (2016). 
Additionally, and with the objective of facilitating the comparison between the different identified taxes and their amounts, all currencies related to the identified taxes have been converted to US dollars².

\section{Results}

In order to obtain a global view of tourism taxation, a study was conducted on those indirect taxes, tourism taxes and fees implemented in the main tourism destinations. The identified taxes have been grouped together based on the OECD classification (2014): i) arrival and departure, ii) air transport, iii) hotels and accommodations, iv) tax rates on consumption, v) environment and vi) incentives.

\subsection{Arrival And departure}

The principal taxes included in this category -listed in Annex 1 - are, mainly, visas and, to a lesser extent, others such as taxes on passenger movement, transit fees, exit fees or boarding fees. As for the amount of the distinct taxes, it varies from one country to another, depending, in large part, on the type of visa requested, the duration of the stay in the country or the country of origin. The amount collected with this type of tax tends to be devoted to payment of administrative costs of customs, immigration, visa issue, data processing, and over recent years, also for actions of promoting and marketing of the tourism destination (OECD, 2014).

Of the 50 top destinations based on number of international tourist arrivals, 41 of these implemented some sort of tax that was levied upon arrival to or departure from the tourism destination. The main taxation method used for the distinct countries results from visas; however, other countries use alternative forms of taxation. For example, Australia, in addition to the visas, also implemented a fee of AUD 37.22 for passenger movement. Chile charged USD 30 for boarding rights while Egypt had an arrival fee - whose amount varied based on country of origin - as well as a departure fee that came to USD 20. Malaysia has implemented a security tax of USD 30. The Dominican Republic required the acquisition of a tourism card - whose amount came to USD 10 - as a mandatory requirement for entry into the country. Finally, Portugal implemented various tourism taxes related to the arrival in and departure from the country, specifically, establishing the following: i) a tax for service provision of border controls - paid directly by the operator - ranging between USD 93.35 and USD 351.42 or ships and USD 233.92 in airports, ii) charging of a fee of USD 3.29 per passenger for boarding and disembarkation, iii) departure of ships from the ports is levied with an amount of USD 0.88 per

\footnotetext{
2 The US dollar was used due to its international dominance. The service provided by the European Central Bank, https://sdw.ecb.europa.eu/curConverter.do, was used to convert the different currencies into US dollars on November 29, 2019.
} 
ship and finally, iv) the disembarkation of crews is levied with an amount of USD 1.10.

\subsection{Air traVeL}

As a result of the increase in air travel over the past twenty years, countries have incurred certain costs -infrastructures, security and passenger services, environment - which have led governments to establish a wide range of taxes that are levied on air transport (OECD, 2014). Of the 50 top tourism destinations that were analyzed, tourism taxes on air travel were found in a total of 30 countries (Annex 2). Using different names, linked to the arrival in or departure from the country, the use of airport installations, service fees or security taxes passengers are taxed significantly for their air travel.

The amount of the tax tends to differ between airports within the same country -Germany, India or Canada, as well as other countries - the flight destination - domestic or international - and there tends to be an exemption from the obligation of tax payment for those under two years of age, passengers in transit or diplomats, as is the case in Saudi Arabia, Albania, Mexico, the Dominican Republic, Croatia and India. In other cases, such as Greece (fees for air travel modernization and development), Canada (tax on airport improvement), or India (tax on user development), the amount of the tax collection is devoted to the modernization of the airport infrastructures.

\subsection{HOTEL AND ACCOMMODATION}

Hotel lodging is a fundamental element of all tourism experiences and the most common example of tourism-specific taxes (Gago et al., 2009). Its generalization is due both to the broad base of subjects that can be affected and to the ease of collection (Gooroochurn and Sinclair, 2005). Using distinct names such as Taxe de Séjour in France and Belgium, State Lodging in the USA, Tassa di Soggiorno in Italy, Kurtaxe in Germany, Bed Night in the Czech Republic, or Accommodation Tax in Japan, the governments of the distinct tourism destinations tax overnight hotel stays through the establishment of taxes whose amount tends to differ based on the establishment category (Annex 3).

Of the top 50 tourism destinations worldwide, a total of 18 countries have been identified that tax hotel stays or overnight stays, mainly in the top tourism regions: Europe and North America. The different taxes that are used - from which we exclude the consumption taxes - tend to be established on a regional and local level, granting autonomy to the cities in the establishment of these taxes and granting them an administrative instrument that offers them resources and permits them to adapt to local idiosyncrasies. The amount of the tax can be established according to a fixed daily amount (France, Spain, Italy, or Austria) or by establishing a percentage on the price of the room (USA, Canada, Netherlands or Puerto Rico). 
This type of tax allows for the addressing of the basic objectives derived from tourism taxation (Oom do Valle et al., 2012), becoming a flexible instrument according to the destination, type of accommodation and time of year (Logar, 2010). Oftentimes, their collection is destined to tasks of promotion, marketing and tourism development at a local level (OECD, 2014). Thus, in Switzerland, the amount collected from the additional tax or Beherbergungsabgabe and from the tax on tourism promotion or Tourismusförderungabgabe, is used for the development of services and the undertaking of activities of promotion and marketing of the destination. Something similar occurs in Canada, through the Municipal and Regional District Tax, whose income is devoted to local promotion, mainly in the tourism area; and in Tokyo, Japan, where the income obtained from the Accommodation Tax is devoted to the promotion of tourism and pays for the expenses derived from the development of the city, with the goal of converting it into an attractive international destination.

\subsection{ReduCED RATES OF CONSUMPTION TAX}

The value added tax, sales tax or tax on goods and services are just a few examples of the distinct taxes that are levied on consumption and that represent a major source of income for the public sector (Gooroochurn and Sinclair, 2005). Both local residents as well as tourists - national and international- are taxed on numerous occasions when purchasing products such as food and drinks and when contracting lodging, leisure or transport services.

The distinct taxes that are levied on consumption -value added tax, tax on goods and services - are not in themselves taxes that affect tourism exclusively. However, governments of different states grant differential treatment to the acquisition of certain tourism-related goods and services, such as lodging and restaurant services. Therefore, as reflected in Annex 4, they combine a general tax rate with a reduced rate that taxes the mentioned categories of goods and services with the objective of promoting their purchase or contracting.

Of the 44 destinations that currently apply taxes on consumption, 16 of these combine the general rate with reduced rates that are applicable to hotels and restaurants. While the general rate that is levied on consumption is established at around 20\% -except in Switzerland which sets it at 8\%the reduced rates tend to be situated at around 10\%, acting as instruments of tourism economic policy to motivate consumption or the contracting of services that are directly related to this activity.

\subsection{ENVIRONMENT}

Tourism activity, on some occasions, produces a series of environmental impacts and costs that lead to a more accelerated deterioration of natural resources and environmental degradation. Justification for the implementing of environmental taxes lies in financing the additional public expenses 
incurred by the public sector in order to preserve the tourism spaces from an environmental point of view (Gago and Labandeira, 2004).

Currently, almost all of the countries have implemented a wide range of environmental taxes in sectors such as energy, transportation or on the emission of contaminants (Eurostat, 2016). However, these taxes do not tend to be levied on tourism activities. In this category, a total of 21 countries have been identified as having implemented tourism taxes of an environmental nature on tourism activities (Annex 5).

In some cases, such as France, Mexico, Egypt, Australia, Poland, Greece or Croatia, said taxes are established with the goal of protecting natural spaces of special interest, for their natural or historic value, as is the case of the Great Barrier Reef in Australia or the main tourism attractions of Egypt - Uadi AlHitan, Wadi El Rayan, the protected area of Saint Catherine, Ras Muhammad National Park, Tiran Island and Camel Valley.

In addition, and in order to reduce acoustic contamination, other countries such as France, Australia, Italy, Turkey, Germany, Japan, Canada, the Netherlands, the Republic of Korea and Switzerland tax the emission of sounds from aircrafts, establishing the amount of said taxes based on the aircraft category.

Environmental quality is a fundamental element for the development of tourism activity in any destination. In this way, both governments -interested in the sustainable use of local resources - as well as tourism companies - linked to a geographic spot for the development of an economic activity - make investments to maintain the environmental quality of the destination. These efforts, based on investments, are taken into account in certain tourist categories, which are willing to pay more to visit high quality environmental destinations (Clewer, 1992; Huybers and Bennett, 2000; Sinclair and Stabler, 1997).

\subsection{INCENTIVES}

The governments of distinct countries attempt to motivate investment through certain mechanisms that reduce or alleviate the fiscal load of certain activities. Some examples of these fiscal incentives, as included in Annex 6 , include certain fiscal deductions in income tax, fiscal incentives for investment, eligible costs and the exemption from indirect taxes in activities related to the tourism activity. We are not therefore talking about taxes, but rather, about instruments of fiscal tourism policy.

Of the top tourism destinations worldwide, eight of these have revealed having tax incentives. In countries such as France, Greece and Australia the tax incentives are linked to the entry of major real estate investments whose destination is tourism lodging. In the case of Poland, and in order to stimulate agro-tourism as well as the development of rural areas and to permit farmers to obtain additional income other than their main activity, an exemption was introduced in 1995 (OECD, 2014) on the rental tax for those individuals renting rooms out of their properties in rural areas. 


\section{ConcLusions}

UNWTO (2016) considers the tourist phenomenon will continue to expand, becoming the most relevant activity in the world, which will lead to an increase in competition among destinations. The tourist experience and the evaluation carried out by the tourist will depend, to a great extent, on the adequate public provision of goods and services. If these are not provided optimally, either in terms of quantity or quality, the destination will not meet the tourists' previous expectations, as the destination will be less attractive and consequently will lose competitiveness. Therefore, the public authorities obviously have a direct impact on several determinants of tourism competitiveness.

As a result, the degree of public intervention plays a fundamental role in the success or failure of this activity, and the financial capacity of the public authorities is an essential element to promote the competitiveness of the destination.

According to the research conducted, of the 50 main tourism destinations based on number of international tourism arrivals, incentives have been identified -understood as an instrument of tourism taxation policy, or taxes in any of their modalities, be it tributes or fees - that are levied upon tourism activities, in 49 of these destinations (Annex 7).

Only in the case of Hong Kong was it not possible to identify any tourism tax and/or incentive. Therefore, tourism taxation is a widely accepted reality in the top tourism destinations.

France and Portugal have implemented taxes and/or incentives in each of the six categories, whereas other countries such as Austria, Croatia, the Czech Republic and Switzerland have done so in five of the six categories all except for the incentives. In addition, the US, Spain, Germany, Mexico, Greece, Canada, Poland, the Netherlands, Hungary and Egypt use four of the six categories. The analysis carried out suggests that the governments of the top tourism destinations have implemented a taxation or incentives measure in about three (2.7) of the six categories defined by the OECD.

The governments use the transversal nature of the tourism activity to establish fiscal policies in those sectors that are directly or indirectly influenced by said economic activity.

In this way, and based on the results obtained, it may be concluded that the establishment of this wide range of fiscal instruments contributes to the increase in public revenues in all taxation categories defined by the OECD, except for that of incentives, which should be treated as an instrument of fiscal tourism policy, which results in a greater competitiveness of the destination.

This is due to the fact that the creation of taxes, tributes and fees that are levied on tourism acts may finance the provision of goods (Greece, Japan, Croatia, Canada and Spain), compensate for the costs resulting from the service provision (Australia, the US, Turkey, Thailand, Greece, Japan, Portugal, Egypt, India, Spain, Greece, Canada, Switzerland, South Africa, Belgium, Argentina and Albania), or finance the administrative costs resulting from visa issue, as is 
the case with the tax associated with the administration of Schengen visas in France, Spain, Portugal, Austria, Poland, the Netherlands, Hungary, the Czech Republic and Switzerland.

In addition, the establishment of this amalgam of taxes helps correct the negative externalities caused by the tourism activity, through the creation of environmental protection taxes, without prejudice to the promotion of the consumption of goods and the contracting of services - through reduced rates for consumption that favors their acquisition - and the influx of investments -incentives.

Finally, tourism taxation contributes to supporting the expenses incurred in tasks such as promotion and marketing - Tokyo in Japan, Canada, the autonomous community of Catalonia in Spain and Switzerland- or to the modernization of infrastructures - Greece, India and Canada - an aspect of vital importance to this highly competitive environment in which the tourism activity is situated.

\section{REFERENCES}

Air Canada. (2017): What are the additional charges in my Fare? Retrieved November 10, 2017, from https://beta.aircanada.com/content/dam/ aircanada/portal/html/dailog-box/booking-flow/surcharges_en.html?acid= beta|redirect|aircanada.com|NoBar

Air India. (2017): Explanation of Taxes, Fees \& Charges. Retrieved September 7, 2017, from http://www.airindia.in/explanation-of-taxes-fees-charges.htm

Athens International Airport. (2017): Aeronautical Charges. Retrieved September 20, 2017, from https://www.aia.gr/userfiles/85ab214c-4e7b4639-83ca-a1fb2a24fc19/Charges_072015.pdf

Bokobo, S. (1999): "La fiscalidad de las prestaciones turísticas: la posibilidad de que las Comunidades Autónomas establezcan la tasa turística", Revista de Derecho Financiero y Hacienda Pública, 102, 243-260.

Besculides, A., Lee, M., \& McCormick, P. (2002): "Residents perceptions of the cultural benefits of tourism", Annals of Tourism Research, 29, 303-319.

Brazilian Ministry of Foreign Relations. (2017): Vistos para viajar ao Brasil. Retrieved December 8, 2017, from http://www.portalconsular.itamaraty.gov. br/vistos

British Columbia. (2019): Municipal \& Regional District Tax. Retrieved December 9, 2019, from https://www.destinationbc.ca/what-we-do/ funding-sources/mrdt/faq/

Brussels Airport. (2017): Charges and Fees. Retrieved December 1, 2017 , from https://www.brusselsairport.be/en/airport-operations/airportcharges

Buhalis, D. (2000): "Marketing the competitive destination of the future", Tourism Management, 23, 99-116. 
Cambodia Airports. (2017): Tourist Fees and charges. Retrieved November 25, 2017, from http://www.cambodia-airports.aero/en/our-business/airlinespartners/fees-charges\#anchor

Cárdenas-García, P. J., Sánchez-Rivero, M., \& Pulido-Fernández, J. I. (2015): "Does Tourism Growth Influence Economic Development?", Journal of travel Research, 54(2), 206-221.

Cetin, G., Alrawadieh, Z., Dincer, M. Z., Istanbullu Dincer, F., \& Ioannides, D. (2017): "Willingness to Pay for Tourist Tax in Destinations: Empirical Evidence from Istanbul”, Economies, 5, 2-21.

Chen, C. Y. (2008): "Evaluating the Competitiveness of the Tourism Industry in Cambodia: Self-Assessment from Professionals", Asia Pacific Journal of Tourism Research, 13 (1), 41-66.

Chen, C. F., \& Chiou-Wei, S. (2009): "Tourism expansion, tourism uncertainty and economic growth: New evidence from Taiwan and Korea”, Tourism Management, 30, 812-818.

Clarke, H., \& Ng, Y. (1993): "Tourism, Economic Welfare and Efficient Pricing”, Annals of Tourism. Research, 20, 613-632.

Clewer, A., Pack, A., \& Sinclair, M. T. (1992): "Price competitiveness and inclusive tour holidays in European cities", Choice and Demand in Tourism, 123-143.

Consulate General of the Kingdom of Morocco. (2017): Visa application. Retrieved December 10, 2017, from http://www.moroccanconsulate.com/ visa.cfm

Costa, A. (2004): Análisis de los efectos del turismo sobre los gastos públicos locales: aplicación al caso de los municipios españoles. Discussion Paper, XI Encuentro de Economía Pública. Barcelona, February 2003.

Crouch, G., \& Ritchie, J. R. (1999): "Tourism, competitiveness and societal prosperity", Journal of Business Research, 44, 137-152.

Department of Home Affairs -Australian Government-. (2017): Electronic Travel Authority. Retrieved October 29, 2017, from https://www.eta. homeaffairs.gov.au/ETAS3/etas

Díaz, F. M. (2006): Política turística: La competitividad y sostenibilidad de los destinos turísticos. Tirant Lo Blanch: Valencia.

Directorate General of Inmigration -Ministry of Law and Human Rights of Indonesia-. (2017): Countries Get Visa. Retrieved November 20, 2017, from http://www.imigrasi.go.id/index.php/en/berita/berita-utama/998-169countries-get-visa-free-facility

Durbarry, R., \& Sinclair, M. T. (2001). “Tourism Taxation in the UK”, Discussion Paper No. 2000/0, Tourism and Travel Research Institute. University of Nottingham: Nottingham.

Dwyer, L., \& Kim, Ch. (2003): “Destination competitiveness: determinants and indicators”, Current Issues in Tourism, 6(5), 369-414.

Embassy of the Islamic Republic of Iran Madrid. (2017): Retrieved December 6, 2017, from http://madrid.mfa.ir/index.aspx?fkeyid = \&siteid = 423\&pag eid $=29265$ 
Enright, M., \& Newton, J. (2004): “Tourism Destination Competitiveness: A Quantitative Approach", Tourism Management, 25 (6), 777-788.

Eurostat. (2016): Environmental tax statistics. Retrieved December 7, 2017, from https://ec.europa.eu/eurostat/statistics-explained/index.php/ Environmental_tax_statistics

Federal Aviation Administration. (2019): Passenger Facility Charge (PFC). Retrieved December 2, 2019, from https://www.faa.gov/airports/pfc/

Forsyth, P., \& Dwyer, L. (2002): "Market Power and the Taxation of Domestic and International Tourism", Tourism Economics, 8, 377-399.

Gago, A., \& Labandeira, X. (2001): “Turismo y Fiscalidad Ambiental”, Papeles de Economía Española, 87, 179-186.

Gago, A., Labandeira, X., \& Rodríguez, M. (2004): "La imposiciōn del turismo", Mediterráneo Económico, 5, 105-117.

Gago, A., Labandeira, X., Picos, F., \& Rodríguez, M. (2009): "Specific and general taxation of tourism activities. Evidence from Spain”, Tourism Management, 30(3), $381-392$.

García, A., \& Siles, D. (2015): "Como mejorar la competitividad turística de un destino: Análisis del mediterráneo español y recomendaciones a los gestores de los destinos", Revista de Análisis Turístico, (19), 1-11.

General Department of Taxation of Ministry of Economy and Finance. (2017): Accommodation Tax. Retrieved December 13, 2017, from http://www.tax. gov.kh/en/bacc.php

General Directorate Of State Airports Authority -Republic of Turkey-. (2015): Retrieved December 14, 2017, from https://centreforaviation.com/data/ profiles/air-traffic-management/general-directorate-of-state-airportsauthority-dhmi-turkey

General Management of Internal Taxes (2017): Retrieved December 14, 2017, from https://dgii.gov.do/sobreTarjetaTurista/Paginas/preguntasFrecuentes. aspx

Geneva Airport. (2017): Airport charges and services. Retrieved October 2, 2017, from https://www.gva.ch/en/Downloads/Professionnels/Airportcharges-and-services.pdf

Gooroochurn, N., \& Sinclair, M. T. (2003): The Welfare Effects of Tourism Taxation. Tourism and Travel Research Institute. University of Nottingham: Nottingham.

Gooroochurn, N., \& Sinclair, M. T. (2005): “Economics of Tourism Taxation: Evidence from Mauritius”, Annals of Tourism Research, 32(2), 478-798.

Gooroochurn, N., \& Sugiyarto, G. (2005): "Competitiveness Indicators in the Travel and Tourism Industry", Tourism Economics, 11 (1), 25-43.

Government of Canada. (2017): Electronic Travel Authorization: What you need to know. Retrieved December 10, 2017, from https://www.canada. ca/en/immigration-refugees-citizenship/news/video/electronic-travelauthorization-what-you-need-know.html 
Government of Macao -Corpo de Polícia de Segurança Pública-. (2016): Entry and Exit of Non-residents. Retrieved December 2, 2017, from http://www. fsm.gov.mo/psp/eng/edon.html

Hall, C. M. (2000): Tourism planning. Policies, processes and relationships, Pearson Education: Harlow.

Hazinski, T., \& Hansel, J. (2019): 2019, HVS Lodging Tax Report -USA-. Retrieved December 9, 2019, from https://www.hvs.com/article/86072019-hvs-lodging-tax-report-usa

Hiemstra, S., \& Ismail, J. A. (1992). "Analysis of Room Taxes Levied on the Lodging Industry", Journal of Travel Research, 31 (1), 42-49.

Holzner, M. (2011): "Tourism and economic development: The beach disease?", Tourism Management, 32, 922-933.

HOSTELTUR (2019): Tasas turīsticas en España y Europa. Retrieved December 9, 2019, from https://www.hosteltur.com/130006_tasas-turisticas-enespana-y-en-europa-en-2019-lo-que-hay-que-pagar.html

Hughes, H. L. (1981): "A tourism tax, the cases for and against", International Journal of Tourism Management, 2(3), 196-206.

Huybers, T., \& Bennett, J. (2000): “Impact of the environment on holiday destination choices of prospective UK tourists: implications for Tropical North Queensland", Tourism Economics, 6(1), 21-46.

ICEX -Secretary of State for Commerce, Ministry of economy, industry and competitiveness, Gobierno de España-. (2017): Red de Oficinas Económicas y Comerciales de España en el Exterior. Retrieved December 18 , 2017, from http://www.icex.es/icex/es/navegacion-principal/todosnuestros-servicios/informacion-de-mercados/paises/mapa/index.html

Ihalanayake, R., \& Divisekera, S. (2006): "The tourism tax burden: evidence from Australia”, Tourism Economics, 12(2), 247-262.

International Air Transport Association -IATA-. (2017): Customs, Currency \& Airport Tax regulations. Retrieved September 29, 2017, from https://www. iatatravelcentre.com/customs-currency-airport-tax-regulations.htm

Jensen, T. C., \& Wanhill, S. (2002): “Tourism's Taxing Times: Value Added Tax in Europe and Denmark”, Tourism Management, 23, 67-79.

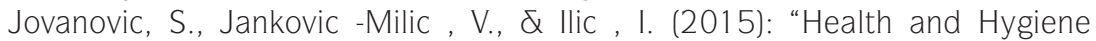
Importance for the Improvement of Tourism Sector Competitiveness in Serbia and the South-eastern Europe Countries", Procedia Economics and Finance, 19, 373-382.

Kerr, W. (2003): Tourism public policy, and strategic management of failure. Elsevier: Oxford.

Kim, H. J., Chen, M. H., \& Jang, S. C. (2006). "Tourism Expansion and Economic Development: The Case of Taiwan”, Tourism Management, 27(5), 925-933.

Korea Official Development Assistance. (2017): Air Ticket Solidarity Levy. Retrieved December 18, 2017, from https://www.odakorea.go.kr/eng.etc. AirTicketSolidarityLevy.do 
Lillo, A., Ramón, A. B., \& Sevilla, M. (2007): "El capital humano como factor estratégico para la competitividad del sector turístico”, Cuadernos de turismo, (19), 47-69.

Litvin, S., Crotts, J., Blackwell, C., \& Styles, A. (2006): "Expenditures of Accommodations Tax Revenue: A South Carolina Study", Journal of Travel Research, 45(2), 150-157.

Logar, I. (2010): "Sustainable tourism management in Crikvenica, Croatia: an assessment of policy instruments", Tourism Management, 31 (1), 125-135.

Ma, M., \& Hassink, R. (2013): "An evolutionary perspective on tourism area development", Annals of Tourism Research, 41, 89-109.

Mangion, M. L., Durbarry, R., \& Sinclair, M. T. (2005): "Tourism Competitiveness: Price and Quality", Tourism Economics, 11 (1), 45-68.

McAleer, M., Shareef, R., \& Da Veiga, B. (2005): Risk management of daily tourist tax revenues for the Maldives. Discussion Paper 137-2005, Fondazione Eni Enrico Mattei, Milan.

McIntosh, R., \& Goeldner, C. (1 990): Tourism Principles, Practices, Philosophies. Wiley: New York.

Ministry of Foreign Affairs \& International Cooperation -Kingdom of Cambodia-. (2017): Tourist visa information. Retrieved November 14 , 2017, from https://www.evisa.gov.kh/

Ministry of justice and human rights. (2017): Aranceles: Valores de la tasa de servicio de seguridad. Retrieved September 18, 2017, from http://servicios. infoleg.gob.ar/infolegInternet/verNorma.do?id = 202200

Ministry of Labour, Immigration and Population -The Republic of the Ujnion of Myanmar-. (2016): Retrieved December 1, 2017, from https://evisa.moip. gov.mm/

Molina, R., Ochoa, M., \& Gil. A. M. (2014): "Public policies and tourism marketing. An analysis of the competitiveness on tourism in Morelia, Mexico and Alcala de Henares, Spain", Procedia Social and Behavioral Sciences, 148, 146-152.

Murphy, P., Pritchard, M.P., \& Smith, B. (2000): “The destination product and its impact on traveler perceptions”, Tourism Management, 21 (1), 43-52.

Myers, J., Forsberg, P., \& Holecek, D. (1997). "A Framework for Monitoring Global Travel and Tourism Taxes: the WTTC Tax Barometer", Tourism Economics, 3(1), 5-20.

Narita Airport. (2017). Passenger Service Facility Charge (PSFC) and Passenger Security Service Charge (PSSC). Retrieved December 7, 2017, from https:// www.narita-airport.jp/en/faq_ask/psfc

Nasr, N. (2017): "Raising competitiveness for the Travel and Tourism Industry: the Case of Egypt", International Journal Of Heritage, Tourism and Hospitality, 10(2/2), 1-23.

National Immigration Agency -Ministry of the Interior-. (2016): Regulations Governing Visiting, Residency, and Permanent Residency of Aliens. Retrieved December 2, 2017, from https://www.immigration.gov.tw/5475 /5478/141478/141482/148812/ 
National Immigration Management. (2015): Autorización de viaje electronica. Retrieved December 2, 2017, from http://www.migraciones.gov.ar/ave/ index.htm

OECD (2014): Tourism Trends and Policies 2014. OECD Publishing: Paris.

OECD - Taxbases - Tax Rates of Environmentally Related Taxes-. (2017): Database on Policy Instruments for the Environment. Retrieved November 25, 2017, from https://pinedatabase.oecd.org/

Okumus, F., Umut, A., Izzet, K., \& Walls, A. (2012): "Cultural Tourism in Turkey: A Missed Opportunity”, Journal of Hospitality Marketing \& Management, $21,638-658$.

Oom do Valle, P., Pintassilgo, P., Matias, A., \& André, F. (2012): “Tourist attitudes towards an accommodation tax earmarked for environmental protection: A survey in the Algarve", Tourism Management, 33, 1408-1416.

Page, S. (2009): Tourism management. Managing for change. Elsevier: Oxford. Page, S., \& Connell, J. (2006): The role of the Public Sector in Tourism, In Tourism, A modern synthesis. Thomsom Learning: London, 276-298.

Pastor, L. (2016): "La fiscalidad del turismo desde una perspectiva internacional”, Barataria. Revista Castellano-Manchega de Ciencias Sociales, 20, 147-160.

Philippine Embassy Madrid. (2017): Visado no inmigrante. Retrieved December 1, 2017, from http://www.philembassymadrid.com/visado-no-inmigrante

Ponjan, P., \& Thirawat, N. (2016): "Impacts of Thailand's tourism tax cut: A CGE analysis", Annals of Tourism Research, 61 (8), 45-62.

Puig, I. (2007): "Fiscalidad y sostenibilidad en los destinos turísticos", Estudios turísticos, $181-185$.

Pulido, J. I., \& Cárdenas, P. J. (2012): La política turística en el ámbito local: la gestión pública de destinos. In Política Económica del Turismo. Pirámide: Madrid, 213-232.

Ranson, G. (2014): "Comparison of tax reliefs, tourist taxes and VAT thresholds in Europe: A study for the Cut Tourism VAT campaign". Retrieved November 20, 2017, from http://www.cuttourismvat.co.uk/wp-content/ uploads/2013/08/140614-EU-Tourism-tax-comparison-tables-Final.pdf

Republic of Turkey. (2017): Electronic visa application system. Retrieved December 2, 2017, from http://www.evisa.gov.tr

Ritchie, J. B., \& Crouch, G. I. (2003): The competitive destination: A sustainable tourism perspective. CABI Publishing: Wallingford.

Ryan, C. (2002): "Equity, management, power sharing and sustainability issues of the "new tourism", Tourism Management, 23, 17-26.

Sánchez, M. (2012): "Análisis cuantitativo del impacto económico de la competitividad en destinos turísticos internacionales", Revista de Economía Mundial, 32, 103-125.

Secretary General of Tourism -Spanish Government-. (2008): Modelos de gestión turística. Principios y prácticas. Ministerio de Industria, Turismo y Comercio: Madrid.

Sinclair, T., \& Stabler, M. (1997): The Economics of Tourism. Routledge: London. 
Singapore Government -Immigration \& Checkpoints Authority-. (2017): Apply for entry Visa. Retrieved December 2, 2017, from https://www.ica.gov.sg/ visitor/visitor_entryvisa

Spanish Airports and Air Travel. (2017): Guía de Tarifas. Retrieved September 1, 2017, from http://www.aena.es/csee/ccurl/147/656/Guia\%20de\%20 tarifas\%202017\%20ed\%20octubre.pdf

Suvarnabhumi Airport Thailand. (2017): International Airport Departure Tax. Retrieved December 2, 2017, from http://www.airportsuvarnabhumi.com/ about-suvarnabhumi-airport/bangkok-international-airport-departure-tax/

Tang, C., \&Tan, E. (2015): “Does tourism effectively stimulate Malaysia's economic growth?", Tourism Management, 46, 158-163.

Tax Law on the Royalty for Room Occupancy in the Free State of Puerto Rico. (2003): Retrieved November 20, 2017, from http://www.gdb.pr.gov/ documents/AGuidetoDoingBusinessinPR-II.pdf

Tirana International Airport. (2017): Charges and Incentives. Retrieved December 10, 2017, from http://www.tirana-airport.com/l/6/39/businessto-business/charges-and-incentives/

Tokyo Metropolitan Government Bureau of Taxation. (2019): Retrieved December 2, 2019, from http://www.tax.metro.tokyo.jp/book/ guidebookgaigo/guidebook2019e.pdf\#page $=71$

Tugcu, C. T. (2014): "Tourism and economic growth nexus revisited: A panel causality analysis for the case of the Mediterranean region", Tourism Management, 42, 207-212.

UNCTAD (2013): "Sustainable tourism: Contribution to economic growth and sustainable development", United Nations Conference on Trade and Development, New York, EE.UU.

UNWTO (1998): Tourism taxation. Striking a fair deal. World Tourism Organization: Madrid.

UNWTO (2005): Tourism highlights 2005. UNWTO: Madrid.

UNWTO. (2016): Panorama OMT del turismo internacional, Edición 2016. Retrieved December 2, 2017, from http://www.e-unwto.org/doi/ pdf/10.18111/9789284418152

Vietnam Airlines. (2017): Taxes, fees and charges. Retrieved October 15, 2017, from https://www.vietnamairlines.com/us/en/plan-book/book-flightnow/taxes-fee-charges-surcharges/passenger-service-charges-securityscreening-service-charges-and-value-added-tax

Webster, C., \& Ivanov, S. (2014): "Transforming competitiveness into economic benefits: Does tourism stimulate economic growth in more competitive destinations?", Tourism Management, 40, 137-140.

WTTC -World Travel and Tourism Council-. (2005): Progress and priorities 2005-06, World Travel and Tourism Council, UK. 


\section{AnNeXes}

AnNeX 1. Arrival and departure taXes IN THE tOP tOURISM DESTINATIONS

\begin{tabular}{|c|c|c|c|c|}
\hline Country & Arrival-departure taxes & Tax amount* & \begin{tabular}{|l|}
$\begin{array}{l}\text { \$ equi- } \\
\text { valence }\end{array}$ \\
\end{tabular} & Source \\
\hline Australia & $\begin{array}{l}\text { Fee for passenger movement } \\
\text { Visa }\end{array}$ & $\begin{array}{l}\text { AUD } 55.00 \\
\text { AUD } 20.00\end{array}$ & $\begin{array}{l}37.22 \\
13.53\end{array}$ & $\begin{array}{l}\text { (OECD, 2014) } \\
\text { (Department of Home Affairs, } \\
\text { 2017) }\end{array}$ \\
\hline Chile & Boarding rights & US\$ 30.00 & 30 & (OECD, 2014) \\
\hline Egypt & $\begin{array}{l}\text { Arrival fee } \\
\text { Departure fee }\end{array}$ & $\begin{array}{l}\text { Varies based } \\
\text { on country } \\
\text { of origin } \\
\text { US\$ } 20.00\end{array}$ & 20.00 & (OECD, 2014) \\
\hline Malaysia & Security tax & $\begin{array}{l}\text { RM } 6.00- \\
45.00\end{array}$ & $\begin{array}{l}1.44- \\
10.77 \\
\end{array}$ & (ICEX, 2017) \\
\hline Portugal & $\begin{array}{l}\text { Service provision tax at border } \\
\text { controls } \\
\text { Passenger boarding and disem- } \\
\text { barking } \\
\text { Departure of ships from ports } \\
\text { Disembarkation of crews } \\
\text { Administrative fee for Schengen } \\
\text { visas }\end{array}$ & $\begin{array}{l}€ 85.00 \text {. } \\
€ 320.00 \\
\text { ships } \\
€ 213.00 \\
\text { airports } \\
€ 3.00 \text { per } \\
\text { passenger } \\
€ 0.80 \text { per } \\
\text { ship } \\
€ 1.00 \\
€ 35.00- \\
60.00\end{array}$ & $\begin{array}{l}93.35- \\
351.42 \\
233.92 \\
3.29 \\
0.88 \\
1.10 \\
38.44- \\
65.89\end{array}$ & (OECD, 2014) \\
\hline France & $\begin{array}{l}\text { Administrative fee for Schengen } \\
\text { visas }\end{array}$ & $\begin{array}{l}€ 35.00- \\
60.00\end{array}$ & \begin{tabular}{|l|}
$38.44-$ \\
65.89 \\
\end{tabular} & (OECD, 2014) \\
\hline Spain & $\begin{array}{l}\text { Administrative fee for Schengen } \\
\text { visas }\end{array}$ & $\begin{array}{l}€ 35.00- \\
60.00\end{array}$ & $\begin{array}{l}38.44- \\
65.89 \\
\end{array}$ & (OECD, 2014) \\
\hline Austria & $\begin{array}{l}\text { Administrative fee for Schengen } \\
\text { visas }\end{array}$ & $\begin{array}{l}€ 35.00- \\
60.00 \\
\end{array}$ & \begin{tabular}{|l|}
$38.44-$ \\
65.89 \\
\end{tabular} & (OECD, 2014) \\
\hline Poland & $\begin{array}{l}\text { Administrative fee for Schengen } \\
\text { visas }\end{array}$ & $\begin{array}{l}€ 35.00- \\
60.00\end{array}$ & \begin{tabular}{|l|}
$38.44-$ \\
65.89
\end{tabular} & (OECD, 2014) \\
\hline Netherlands & $\begin{array}{l}\text { Administrative fee for Schengen } \\
\text { visas }\end{array}$ & $\begin{array}{l}€ 35.00- \\
60.00\end{array}$ & \begin{tabular}{|l|}
$38.44-$ \\
65.89 \\
\end{tabular} & (OECD, 2014) \\
\hline Hungary & $\begin{array}{l}\text { Administrative fee for Schengen } \\
\text { visas }\end{array}$ & \begin{tabular}{|l|}
$€ 35.00-$ \\
60.00 \\
\end{tabular} & \begin{tabular}{|l|}
$38.44-$ \\
65.89 \\
\end{tabular} & (OECD, 2014) \\
\hline Czech Rep. & $\begin{array}{l}\text { Administrative fee for Schengen } \\
\text { visas }\end{array}$ & $\begin{array}{l}€ 35.00- \\
60.00\end{array}$ & \begin{tabular}{|l|}
$38.44-$ \\
65.89 \\
\end{tabular} & (OECD, 2014) \\
\hline Switzerland & $\begin{array}{l}\text { Administrative fee for Schengen } \\
\text { visas }\end{array}$ & $\begin{array}{l}€ 35.00- \\
60.00 \\
\end{array}$ & \begin{tabular}{|l|}
$38.44-$ \\
65.89 \\
\end{tabular} & (OECD, 2014) \\
\hline Albania & Visa facilitation agreement with EU & $€ 35.00$ & 38.44 & (OECD, 2014) \\
\hline Ukraine & Visa facilitation agreement with EU & $€ 35.00$ & 38.44 & (OECD, 2014) \\
\hline USA & Visa & US\$ 14.00 & 14.00 & (ICEX, 2017) \\
\hline Puerto Rico & Visa & US\$ 14.00 & 14.00 & (ICEX, 2017) \\
\hline China & Visa & $n / a$ & $\mathrm{n} / \mathrm{a}$ & (ICEX, 2017) \\
\hline Russian Fed. & Visa & $€ 35.00$ & 38.44 & (ICEX, 2017) \\
\hline Saudi Arabia & Visa & US\$ 66.67 & 66.67 & (ICEX, 2017) \\
\hline Jordan & Visa & $€ 67.50$ & 74.13 & (ICEX, 2017) \\
\hline Turkey & Visa & Varies & Varies & (Republic of Turkey, 2017) \\
\hline Canada & Visa & Can\$ 7.00 & 5.26 & (Government of Canada, 2016) \\
\hline Macao & Visa & $\begin{array}{l}\text { MOP } 50.00 \\
-200.00\end{array}$ & $\begin{array}{ll}6.21- \\
24.86\end{array}$ & $\begin{array}{l}\text { (Police and Public Security } \\
\text { Corps of Macao, 2016) }\end{array}$ \\
\hline
\end{tabular}




\begin{tabular}{|c|c|c|c|c|}
\hline Singapore & Visa & S\$30.00 & 21.94 & (Singapore Government, 2017) \\
\hline Taiwan & Visa & $n / a$ & $\mathrm{n} / \mathrm{a}$ & $\begin{array}{l}\text { (National Immigration Agency, } \\
\text { 2016) }\end{array}$ \\
\hline Morocco & Visa & $\begin{array}{l}\text { US\$ 23.85- } \\
35.80\end{array}$ & $\begin{array}{l}23.85- \\
35.80\end{array}$ & $\begin{array}{l}\text { (Consulate General of the King- } \\
\text { dom of Morocco, 2017) }\end{array}$ \\
\hline Brazil & Visa & $\begin{array}{l}\text { Varies based } \\
\text { on consulate }\end{array}$ & Varies & $\begin{array}{l}\text { (Brazilian Ministry of Foreign } \\
\text { Relations, 2017) }\end{array}$ \\
\hline Argentina & Visa & $\begin{array}{l}\text { ARS } 1.000- \\
2.000\end{array}$ & $\begin{array}{l}16.73- \\
33.46\end{array}$ & $\begin{array}{l}\text { (National Immigration Manage- } \\
\text { ment, 2015) }\end{array}$ \\
\hline Philippines & Visa & $\begin{array}{l}€ 30.00- \\
40.00\end{array}$ & $\begin{array}{l}32.95- \\
43.93\end{array}$ & $\begin{array}{l}\text { (Philippine Embassy Madrid, } \\
\text { 2017) }\end{array}$ \\
\hline Cambodia & Visa & US\$ 37.00 & 37.00 & $\begin{array}{l}\text { (Ministry of Foreign Affairs } \Sigma \text { In- } \\
\text { ternational Cooperation, 2017) }\end{array}$ \\
\hline Myanmar & Visa & US\$ 50.00 & 50.00 & $\begin{array}{l}\text { (Ministry of Labor, Immigration } \\
\text { and Population, 2016) }\end{array}$ \\
\hline Indonesia & Visa & US\$ 35.00 & 35.00 & $\begin{array}{l}\text { (Directorate General of Immigra- } \\
\text { tion, 2017) } \\
\end{array}$ \\
\hline Tunisia & Visa & $\mathrm{n} / \mathrm{a}$ & $\mathrm{n} / \mathrm{a}$ & $\mathrm{n} / \mathrm{a}$ \\
\hline Mexico & Visa & MXN 295 & 15.10 & (OECD, 2014) \\
\hline Croatia & Visa & $€ 35.00$ & 38.44 & (OECD, 2014) \\
\hline South Africa & Visa & R 425.00 & 28.95 & (OECD, 2014) \\
\hline India & Visa & $\mathrm{n} / \mathrm{a}$ & $\mathrm{n} / \mathrm{a}$ & (ICEX, 2017) \\
\hline Vietnam & Visa & $\begin{array}{l}\$ 17.00- \\
25.00\end{array}$ & $\begin{array}{l}17.00 \\
- \\
25.00\end{array}$ & (ICEX, 2017) \\
\hline Dom. Rep. & Tourism card & US\$ 10.00 & 10.00 & $\begin{array}{l}\text { (General management of inter- } \\
\text { nal taxes,2017) }\end{array}$ \\
\hline Iran & Visa & $€ 50.00$ & 54.91 & $\begin{array}{l}\text { (Embassy of the Islamic Republic } \\
\text { of Iran Madrid, 2017) }\end{array}$ \\
\hline
\end{tabular}

Source: Author's own creation. 
AnNex 2. Air travel taXes In the top tourism destinations

\begin{tabular}{|c|c|c|c|c|}
\hline Country & Air tax & Tax amount & $\begin{array}{l}\text { \$ equi- } \\
\text { valence }\end{array}$ & Source \\
\hline France & $\begin{array}{l}\text { Civil aviation tax } \\
\text { Tax on plane ticket solidarity }\end{array}$ & $\begin{array}{l}€ 4.31- \\
7.04 \\
€ 1.00- \\
4.00\end{array}$ & $\begin{array}{l}4.73- \\
7.73 \\
1.10- \\
4.39\end{array}$ & (OECD, 2014) \\
\hline USA & $\begin{array}{l}\text { Fees for the use of the airport } \\
\text { installations }\end{array}$ & $\begin{array}{l}€ 4.50- \\
18.00\end{array}$ & \begin{tabular}{|l|}
$4.94-$ \\
19.77 \\
\end{tabular} & $\begin{array}{l}\text { (Federal Aviation Administration, } \\
\text { 2019) }\end{array}$ \\
\hline Spain & Air security tax & $\begin{array}{l}€ 0.18- \\
0.60\end{array}$ & $\begin{array}{l}0.20- \\
0.66\end{array}$ & $\begin{array}{l}\text { (Spanish Airports and Air Travel, } \\
\text { 2017) }\end{array}$ \\
\hline Turkey & $\begin{array}{l}\text { International passenger service } \\
\text { National passenger service }\end{array}$ & $\begin{array}{l}€ 5.00- \\
15.00 \\
€ 2.00- \\
6.00\end{array}$ & $\begin{array}{l}5.49- \\
16.47 \\
2.20- \\
6.59\end{array}$ & $\begin{array}{l}\text { (General Directorate Of State } \\
\text { Airports Authority, 2015) }\end{array}$ \\
\hline Germany & Tax on German plane ticket & $\begin{array}{l}€ 7.50- \\
45.00\end{array}$ & $\begin{array}{l}8.24- \\
49.42 \\
\end{array}$ & (OECD, 2014) \\
\hline $\begin{array}{l}\text { United } \\
\text { Kingdom }\end{array}$ & Tax on airline passengers & $\begin{array}{l}£ 13.00- \\
450.00\end{array}$ & \begin{tabular}{|l|}
$16.75-$ \\
579.87 \\
\end{tabular} & (OECD, 2014) \\
\hline Mexico & Int. departures airport tax & $\begin{array}{l}\text { US\$ } 18.00 \\
-48.00 \\
\end{array}$ & $\begin{array}{l}18.00- \\
48.00\end{array}$ & $\begin{array}{l}\text { (International Air Transport Asso- } \\
\text { ciation, 2017) }\end{array}$ \\
\hline Thailand & Passenger service fees & $\begin{array}{l}\text { THB } 100- \\
700\end{array}$ & $\begin{array}{l}3.31- \\
23.15\end{array}$ & $\begin{array}{l}\text { (Suvarnabhumi Airport Thailand, } \\
\text { 2017) }\end{array}$ \\
\hline Austria & Tax on air transport & $\begin{array}{l}€ 7.00- \\
35.00 \\
\end{array}$ & $\begin{array}{l}7.69- \\
38.44 \\
\end{array}$ & (OECD, 2014) \\
\hline Greece & $\begin{array}{l}\text { Passenger service fees in terminal } \\
\text { Fees for air travel modernization and } \\
\text { development } \\
\text { Security fees }\end{array}$ & $\begin{array}{l}€ 8.51- \\
12.16 \\
€ 12.00- \\
22.00 \\
€ 5.00\end{array}$ & \begin{tabular}{|l|}
$9.35-$ \\
13.35 \\
$13.18-$ \\
24.16 \\
5.49 \\
\end{tabular} & $\begin{array}{l}\text { (OECD, 2014) } \\
\text { (Athens International Airport, } \\
\text { 2017) }\end{array}$ \\
\hline Canada & $\begin{array}{l}\text { Tax on airport improvement } \\
\text { Airline traveler security fees }\end{array}$ & \begin{tabular}{|l|} 
Distinct in \\
each airport \\
Can\$2 25.91 \\
\end{tabular} & \begin{tabular}{|l|} 
Varies \\
19.47 \\
\end{tabular} & $\begin{array}{l}\text { (International Air Transport Asso- } \\
\text { ciation, 2017) } \\
\text { (Air Canada, 2017) } \\
\end{array}$ \\
\hline $\begin{array}{l}\text { Rep. of } \\
\text { Korea }\end{array}$ & Tax on plane ticket solidarity & \begin{tabular}{|l|} 
KRW \\
1.000 .00 \\
\end{tabular} & 0.85 & $\begin{array}{l}\text { (Korea Official Development Assis- } \\
\text { tance, 2017) }\end{array}$ \\
\hline Japan & $\begin{array}{l}\text { Passenger service and security fees } \\
\text { Passenger service fees }\end{array}$ & $\begin{array}{l}¥ 520.00 \\
¥ 510.00- \\
2.090 .00\end{array}$ & \begin{tabular}{|l|}
4.74 \\
$4.65-$ \\
19.06 \\
\end{tabular} & (Narita Airport, 2017) \\
\hline $\begin{array}{l}\text { Saudi } \\
\text { Arabia }\end{array}$ & Airport tax & SAR 50.00 & 13.33 & $\begin{array}{l}\text { (International Air Transport Asso- } \\
\text { ciation, 2017) } \\
\end{array}$ \\
\hline Croatia & Departure tax & $\begin{array}{l}€ 0.68- \\
1.37\end{array}$ & $\begin{array}{l}0.75- \\
1.50\end{array}$ & (OECD, 2014) \\
\hline Czech Rep. & $\begin{array}{l}\text { Departure tax } \\
\text { Transit tax } \\
\end{array}$ & $\begin{array}{l}\text { CZK } 565.00 \\
\text { CZK } 205.00 \\
\end{array}$ & \begin{tabular}{|l|}
24.32 \\
8.82 \\
\end{tabular} & (OECD, 2014) \\
\hline \multirow[t]{2}{*}{ Portugal } & Passenger service fee & $\begin{array}{l}€ 5.95- \\
12.66 \\
\end{array}$ & \begin{tabular}{|l|}
$6.53-$ \\
13.90 \\
\end{tabular} & (OECD, 2014) \\
\hline & Security fee & & & \\
\hline Switzerland & $\begin{array}{l}\text { Passenger departure tax } \\
\text { Security tax }\end{array}$ & $\begin{array}{l}\text { CHF 13.85 } \\
-23.75 \\
\text { CHF 10.35 } \\
\text { Included in } \\
\text { the departu- } \\
\text { re tax }\end{array}$ & $\begin{array}{l}13.83- \\
23.72 \\
10.33\end{array}$ & (Geneva Airport, 2017) \\
\hline Egypt & $\begin{array}{l}\text { Passenger departure tax } \\
\text { Passenger service fee }\end{array}$ & $\begin{array}{l}\text { US\$ } 3.00- \\
15.00 \\
\text { US\$ } 1.00\end{array}$ & \begin{tabular}{|l|}
$3.00-$ \\
15.00 \\
1.00
\end{tabular} & $\begin{array}{l}\text { (International Air Transport Asso- } \\
\text { ciation, 2017) }\end{array}$ \\
\hline
\end{tabular}




\begin{tabular}{|c|c|c|c|c|}
\hline $\begin{array}{l}\text { South } \\
\text { Africa }\end{array}$ & $\begin{array}{l}\text { Passenger departure tax } \\
\text { Passenger service fee } \\
\text { Air travel passenger security fee }\end{array}$ & \begin{tabular}{|l} 
R $100.00-$ \\
190.00 \\
R $120.00-$ \\
328.00 \\
R $42.00-$ \\
242.00
\end{tabular} & $\begin{array}{l}6.81- \\
12.94 \\
8.18- \\
22.35 \\
2.86- \\
16.49\end{array}$ & (OECD, 2014) \\
\hline Belgium & $\begin{array}{l}\text { Security fee } \\
\text { PRM Charge }\end{array}$ & $\begin{array}{l}€ 6.22 \\
€ 0.47\end{array}$ & $\begin{array}{l}6.83 \\
0.52 \\
\end{array}$ & (Brussels Airport, 2017) \\
\hline India & $\begin{array}{l}\text { Tax on user development } \\
\text { Passenger service tax }\end{array}$ & $\begin{array}{l}\text { Distinct in } \\
\text { each airport }\end{array}$ & Varies & (Air India, 2017) \\
\hline Vietnam & Int. passenger service fee & $\begin{array}{l}\text { US } \$ 14.00 \\
-25.00\end{array}$ & $\begin{array}{l}14.00- \\
25.00\end{array}$ & (Vietnam Airlines, 2017) \\
\hline Argentina & $\begin{array}{l}\text { Airport use tax } \\
\text { Security tax }\end{array}$ & $\begin{array}{l}\text { Distinct in } \\
\text { each airport } \\
\text { US\$ } 10.00\end{array}$ & $\begin{array}{l}\text { Varies } \\
10.00\end{array}$ & $\begin{array}{l}\text { (Ministry of justice and human } \\
\text { rights, 2017) }\end{array}$ \\
\hline $\begin{array}{l}\text { Dominican } \\
\text { Rep. }\end{array}$ & Departure tax & US\$ 20.00 & 20.00 & $\begin{array}{l}\text { (International Air Transport Asso- } \\
\text { ciation, 2017) }\end{array}$ \\
\hline Philippines & Travel tax & $\begin{array}{l}\text { PHP } 200.00 \\
-550.00\end{array}$ & $\begin{array}{l}3.93- \\
10.82 \\
\end{array}$ & $\begin{array}{l}\text { (International Air Transport Asso- } \\
\text { ciation, 2017) }\end{array}$ \\
\hline Cambodia & Airport departure tax & $\begin{array}{l}\text { US\$ } 6.00- \\
25.00\end{array}$ & $\begin{array}{l}6.00- \\
25.00\end{array}$ & (Cambodia Airports, 2017) \\
\hline Myanmar & Airport tax & US\$ 10.00 & 10.00 & $\begin{array}{l}\text { (International Air Transport Asso- } \\
\text { ciation, 2017) }\end{array}$ \\
\hline Chile & Passenger boarding right & $\begin{array}{l}\text { US \$ } 2.52- \\
30.00\end{array}$ & $\begin{array}{l}2.52- \\
30.00\end{array}$ & (OECD, 2014) \\
\hline Albania & $\begin{array}{l}\text { Security fee } \\
\text { Passenger fee } \\
\text { Border crossing tax }\end{array}$ & $\begin{array}{l}€ 4.00 \\
€ 5.00- \\
12.50 \\
€ 10.00\end{array}$ & $\begin{array}{l}4.39 \\
5.49 \\
13.73 \\
10.98\end{array}$ & $\begin{array}{l}\text { (Tirana International Airport, } \\
\text { 2017). }\end{array}$ \\
\hline
\end{tabular}

Source: Author's own creation. 
ANNEX 3. HOTEL AND ACCOMMOdATIONS TAXES IN THE TOP TOURISM DESTINATIONS

\begin{tabular}{|c|c|c|c|c|}
\hline Country & Cities & Tax amount & $\begin{array}{l}\text { \$ equiva- } \\
\text { lence }\end{array}$ & Source \\
\hline \multirow{3}{*}{ France } & Paris & $€ 0.25-5.00$ & $0.28-5.55$ & (HOSTELTUR, 2019) \\
\hline & Marseilles & $€ 0.75-3.00$ & $0.83-3.33$ & \\
\hline & Bordeaux & $€ 0.35-1.45$ & $0.39-1.61$ & \\
\hline \multirow{2}{*}{ Spain } & Barcelona & $€ 1.10-2.25$ & $1.22-2.50$ & (HOSTELTUR, 2019) \\
\hline & Palma de Mallorca & $€ 2.00-4.00$ & $2.22-4.44$ & \\
\hline \multirow{3}{*}{ USA } & New York & $14.75 \%$ & $14.75 \%$ & (Hazinski and Hansel, 2019) \\
\hline & San Francisco & $16.75 \%$ & $16.75 \%$ & \\
\hline & Los Angeles & $15.50 \%$ & $15.50 \%$ & \\
\hline \multirow{3}{*}{ Italy } & Rome & $€ 4.00-7.00$ & $4.44-7.77$ & (HOSTELTUR, 2019) \\
\hline & Milan & $€ 3.00-5.00$ & $3.33-5.55$ & \\
\hline & Venice & $€ 3.5-5.00$ & $3.88-6.16$ & \\
\hline \multirow{2}{*}{ Germany } & Berlin & $5.00 \%$ & $5.00 \%$ & (HOSTELTUR, 2019) \\
\hline & Frankfurt & $€ 2.00$ & 2.22 & \\
\hline Austria & Vienna & $€ 0.15-3.00$ & $0.17-3.33$ & (HOSTELTUR, 2019) \\
\hline Japan & Tokyo & $¥ 100-200$ & $0.91-1.82$ & $\begin{array}{l}\text { (Tokyo Metropolitan Government } \\
\text { Bureau of Taxation, 2019) }\end{array}$ \\
\hline Canada & Vancouver & $3.00 \%$ & $3.00 \%$ & (British Columbia, 2019) \\
\hline Belgium & Brussels & $€ 4.24$ & & (HOSTELTUR, 2019) \\
\hline \multirow{2}{*}{ Netherlands } & Amsterdam & $7.00 \%$ & $7.00 \%$ & (HOSTELTUR, 2019) \\
\hline & Rotterdam & $6.5 \%$ & $6.5 \%$ & \\
\hline Hungary & Budapest & $4.00 \%$ & $4.00 \%$ & (HOSTELTUR, 2019) \\
\hline Croatia & Dubrovnik & Kn 10.00 & 1.49 & (HOSTELTUR, 2019) \\
\hline Czech Rep. & Prague & CZK 30.00 & 1.30 & (HOSTELTUR, 2019) \\
\hline \multirow{2}{*}{ Portugal } & Lisbon & $€ 2.00$ & 2.22 & (HOSTELTUR, 2019) \\
\hline & Oporto & $€ 2.00$ & 2.22 & \\
\hline \multirow[t]{2}{*}{ Switzerland } & Geneva & $\begin{array}{l}\text { CHF 1.65- } \\
4.75\end{array}$ & $1.67-4.80$ & (Ranson, 2014) \\
\hline & Zurich & CHF 2.5 & 2.53 & \\
\hline Egypt & Cairo & $\begin{array}{l}12 \% \text { on } \\
\text { purchase in } \\
\text { hotels and } \\
\text { restaurants }\end{array}$ & $12 \%$ & (OECD, 2014) \\
\hline Cambodia & Phnom Penh & $2.00 \%$ & $2.00 \%$ & $\begin{array}{l}\text { (General Department of Taxation of } \\
\text { Ministry of Economy and Finance, } \\
2017 \text { ) }\end{array}$ \\
\hline Puerto Rico & San Juan & $7.00 \%$ & $7.00 \%$ & $\begin{array}{l}\text { (Tax Law on the Royalty for Room } \\
\text { Occupancy in the Free State of Puerto } \\
\text { Rico, 2003) }\end{array}$ \\
\hline
\end{tabular}

Source: Author's own creation. 
AnNeX 4. CONSUmption tAXES IN THE tOP TOURISM DESTINATIONS

\begin{tabular}{|c|c|c|c|c|c|c|c|c|}
\hline Country & $\begin{array}{l}\text { General } \\
\text { rate }\end{array}$ & $\begin{array}{l}\text { Reduced } \\
\text { rate }\end{array}$ & & Country & General rate & $\begin{array}{l}\text { Reduced } \\
\text { rate }\end{array}$ & & \\
\hline & & Hotels & $\begin{array}{l}\text { Restau- } \\
\text { rants }\end{array}$ & & & & Hotels & $\begin{array}{l}\text { Restau- } \\
\text { rants }\end{array}$ \\
\hline France & $20 \%$ & $10 \%$ & $10 \%$ & & Hungary & $27 \%$ & $18 \%$ & - \\
\hline Spain & $21 \%$ & $10 \%$ & $10 \%$ & & Croatia & $25 \%$ & $13 \%$ & $13 \%$ \\
\hline Italy & $22 \%$ & $10 \%$ & $10 \%$ & & Czech Rep. & $21 \%$ & $15 \%$ & -- \\
\hline $\begin{array}{l}\text { Ger- } \\
\text { many }\end{array}$ & $19 \%$ & $7 \%$ & & & Morocco & $20 \%$ & $10 \%$ & $10 \%$ \\
\hline Austria & $20 \%$ & $10 \%$ & $10 \%$ & & Portugal & $23 \%$ & $6 \%$ & -- \\
\hline Greece & $23 \%$ & $6,50 \%$ & $13 \%$ & & Switzerland & $8 \%$ & $3,80 \%$ & $3,80 \%$ \\
\hline Poland & $23 \%$ & $8 \%$ & $8 \%$ & & Belgium & $21 \%$ & $6 \%$ & $12 \%$ \\
\hline $\begin{array}{l}\text { Nether- } \\
\text { lands }\end{array}$ & $21 \%$ & $6 \%$ & $6 \%$ & & Tunisia & $18 \%$ & $12 \%$ & $12 \%$ \\
\hline
\end{tabular}

Source: Author's own creation based on the OECD (2014) and ICEX (2017).

ANNEX 5. ENVIRONMENTAL TAXES ON TOURISM IN THE TOP TOURISM DESTINATIONS

\begin{tabular}{|c|c|c|c|}
\hline Country & Environmental taxes related to the tourism activity & Tax amount & \$ equivalence \\
\hline \multirow[t]{3}{*}{ France } & Fees for noise issued by aircrafts & Differs based on the airport & \\
\hline & $\begin{array}{l}\text { Tax on maritime passenger boarding in protected } \\
\text { natural areas }\end{array}$ & $\begin{array}{l}\text { Established based on the } \\
\text { number of passengers entering } \\
\text { the protected area }\end{array}$ & \\
\hline & $\begin{array}{l}\text { Tax on airlines and maritime transport in Corsica } \\
\text { and overseas departments }\end{array}$ & $€ 4.75$ per passenger & 5.22 \\
\hline \multirow[t]{2}{*}{ Mexico } & Tax on aquatic activities in protected areas & MXN 53.97 & 2.76 \\
\hline & Tax on activities in natural protected areas & MXN 26.99 & 1.38 \\
\hline Portugal & $\begin{array}{l}\text { Tax on the certificate of environmental impact } \\
\text { Tax on energy certification and air quality of } \\
\text { constructions, renovations and rental of tourism } \\
\text { establishments }\end{array}$ & $\begin{array}{l}€ 1,500.00 \text { for investments } \\
\text { of up to } € 3 \mathrm{MM} \text { and } 0.05 \% \\
\text { of the value invested for a } \\
\text { maximum of } € 100,000 \\
€ 307.50\end{array}$ & $\begin{array}{l}1647.30- \\
109820.00 \\
337.70\end{array}$ \\
\hline Egypt & $\begin{array}{l}\text { Visitor tickets in the main tourism activities of the } \\
\text { country - Uadi Al-Hitan, Wadi El Rayan, protected } \\
\text { area of Saint Catherine, Ras Muhammad National } \\
\text { Park, Tiran Island and Camel Valley- }\end{array}$ & $\begin{array}{l}\text { Varies based on the tourism } \\
\text { attraction and whether or not } \\
\text { the visitor is a resident of Egypt } \\
\text { or not }\end{array}$ & Varies \\
\hline \multirow[t]{2}{*}{ Australia } & $\begin{array}{l}\text { Environmental management fee for the Great } \\
\text { Barrier Reef }\end{array}$ & AUS $1.75-3.50$ & $1.18-2.37$ \\
\hline & Fees for noise issued by aircrafts & $\begin{array}{l}\text { Varies based on the noise } \\
\text { assessment }\end{array}$ & Varies \\
\hline Brazil & $\begin{array}{l}\text { Environmental preservation tax in cities whose } \\
\text { main economic activity is ecotourism }\end{array}$ & Varies based on city & Varies \\
\hline \multirow[t]{2}{*}{ USA } & $\begin{array}{l}\text { Visitors to the state of Alaska in commercial } \\
\text { passenger ships }\end{array}$ & Varies based on town & Varies \\
\hline & $\begin{array}{l}\text { Tax for vehicle rental in distinct states-Florida, } \\
\text { Kansas, Minnesota- }\end{array}$ & & \\
\hline Italy & Tax on noise issued by aircrafts & $\begin{array}{l}\text { Varies based on the aircraft } \\
\text { category }\end{array}$ & 109.82 \\
\hline
\end{tabular}




\begin{tabular}{|c|c|c|c|}
\hline & Taxes on passengers in air taxis & $\begin{array}{l}€ 100.00 \text { per flight whose } \\
\text { trajectory is over } 100 \mathrm{~km} \text { and } \\
\text { less than } 1500 \mathrm{~km} \text {; } € 200.00 \\
\text { per flight in trajectories of over } \\
1.500 \mathrm{~km}\end{array}$ & 219.64 \\
\hline Turkey & Fees for noise issued by aircrafts & $\begin{array}{l}0.5 \% \text { of the ticket price per } \\
\text { passenger and a pre-establis- } \\
\text { hed tax per ton of transported } \\
\text { merchandise }\end{array}$ & $\begin{array}{l}\% \text { of the } \\
\text { ticket price }\end{array}$ \\
\hline Germany & Fees for noise issued by aircrafts & Varies based on airport & Varies \\
\hline Austria & Air security tax & $€ 8.00$ per passenger & 8.79 \\
\hline Greece & Fee for entry to monuments and national parks & $€ 0.61-3.68$ per visitor & $0.67-4.04$ \\
\hline Japan & Fees for noise issued by aircrafts & Varies based on airport & Varies \\
\hline Canada & Fees for noise issued by aircrafts & Varies based on airport & Varies \\
\hline Poland & Fee for entry into national parks & Varies based on national park & Varies \\
\hline $\begin{array}{l}\text { Nether- } \\
\text { lands }\end{array}$ & Fees for noise issued by aircrafts & $\begin{array}{l}€ 95.75 \text { per unit of noise } \\
\text { produced }\end{array}$ & 105.15 \\
\hline $\begin{array}{l}\text { Rep. of } \\
\text { Korea }\end{array}$ & Fees for noise issued by aircrafts during landing & $n / a$ & $\mathrm{n} / \mathrm{a}$ \\
\hline Croatia & Fee for entry into national parks & $\begin{array}{l}\text { HRK } 30.00-156.00 \text { for } \\
\text { adults and } \\
\text { HRK } 15.00-62.00 \text { for } \\
\text { children }\end{array}$ & $\begin{array}{l}4.43-23.03 \\
2.21-9.15\end{array}$ \\
\hline $\begin{array}{l}\text { Czech } \\
\text { Rep. }\end{array}$ & Fee for visitors in resorts and recreational areas & $n / a$ & $n / a$ \\
\hline $\begin{array}{l}\text { Switzer- } \\
\text { land }\end{array}$ & Fees for noise issued by aircrafts & $\begin{array}{l}\text { Varies based on type of aircra- } \\
\mathrm{ft} \text {, noise category and time of } \\
\text { take off /landing }\end{array}$ & Varies \\
\hline \multirow[t]{2}{*}{ Albania } & Tax for flying over Albanian territory & n/a & $\mathrm{n} / \mathrm{a}$ \\
\hline & Tax on landing, flight and stay of planes & $\begin{array}{l}\text { Varies based on the tons of } \\
\text { weight of the aircraft }\end{array}$ & Varies \\
\hline
\end{tabular}

Source: Author's own creation based on the OECD (2014) and OECD (2017). 
ANNEX 6. FISCAL INCENTIVES OF A TOURISM NATURE IN THE TOP TOURISM DESTINATIONS

\begin{tabular}{|c|c|c|c|}
\hline Country & Fiscal tourism incentives & Quantification of Incentive & \$ equivalence \\
\hline France & $\begin{array}{l}\text { Deduction in real estate investments } \\
\text { destined to tourism rental } \\
\text { Tax credit for "maitres restaurateurs" }\end{array}$ & $\begin{array}{l}\text { Maximum } € 300,000 \\
\text { Grant of up to } 50 \% \text { in certain } \\
\text { expenses }\end{array}$ & $\begin{array}{l}329.46 \\
\% \text { in certain } \\
\text { expenses }\end{array}$ \\
\hline Greece & $\begin{array}{l}\text { Tax exemption for private investments } \\
\text { in hotels and special tourism infrastruc- } \\
\text { ture projects }\end{array}$ & $\begin{array}{l}\% \text { of the expenses of the project, } \\
\text { machinery and equipment acquired }\end{array}$ & $\begin{array}{l}\% \text { of the } \\
\text { expenses }\end{array}$ \\
\hline Poland & $\begin{array}{l}\text { Tax exemption for rental of rooms in } \\
\text { rural areas }\end{array}$ & Tax exemption for rental income & Tax exemption \\
\hline Hungary & $\begin{array}{l}\text { The Széchenyi recreational card offers } \\
\text { additional non-wage benefits to the } \\
\text { worker- lodging, restaurants, theater } \\
\text { tickets, etc. - having more favorable } \\
\text { fiscal conditions than those of the } \\
\text { salaries }\end{array}$ & $\mathrm{n} / \mathrm{a}$ & $\mathrm{n} / \mathrm{a}$ \\
\hline Portugal & $\begin{array}{l}\text { Exemptions and reductions at hotels } \\
\text { and other lodging types, restaurants, } \\
\text { thermal or leisure services }\end{array}$ & $\begin{array}{l}\text { Tax exemptions -Municipal Tax on } \\
\text { Real Estate Property Transmission, } \\
\text { Municipal Tax on Real Estate } \\
\text { Property, Taxes on the General } \\
\text { Inspectorate of Cultural Activities } \\
\text { - and reduction of the stamp duty } \\
\text { when purchasing buildings }\end{array}$ & Tax exemptions \\
\hline Australia & $\begin{array}{l}\text { Favorable tax advantages to hotels, in } \\
\text { order to promote large investments in } \\
\text { the sector } \\
\text { Tourist reimbursement program }\end{array}$ & $\begin{array}{l}\text { Accelerated depreciation of cons- } \\
\text { truction expenses } \\
\text { Refunding of taxes on goods and } \\
\text { services to tourists }\end{array}$ & $\begin{array}{l}\text { Refunding of } \\
\text { taxes }\end{array}$ \\
\hline $\begin{array}{l}\text { South } \\
\text { Africa }\end{array}$ & $\begin{array}{l}\text { Refunding of the added value tax to } \\
\text { foreign visitors }\end{array}$ & $\begin{array}{l}\text { Refunding of the added value tax for } \\
\text { purchases over R } 250\end{array}$ & 17.03 \\
\hline Mexico & $\begin{array}{l}\text { System of refunding of the added } \\
\text { value tax }\end{array}$ & Refunding of $16 \%$ of the total paid & $\begin{array}{l}\% \text { of the total } \\
\text { paid }\end{array}$ \\
\hline
\end{tabular}

Source: Author's own creation based on OECD (2014). 
AnNeX 7. TOURISM tAX CATEGoRIES USED BY THE TOP TOURISM DESTINATIONS

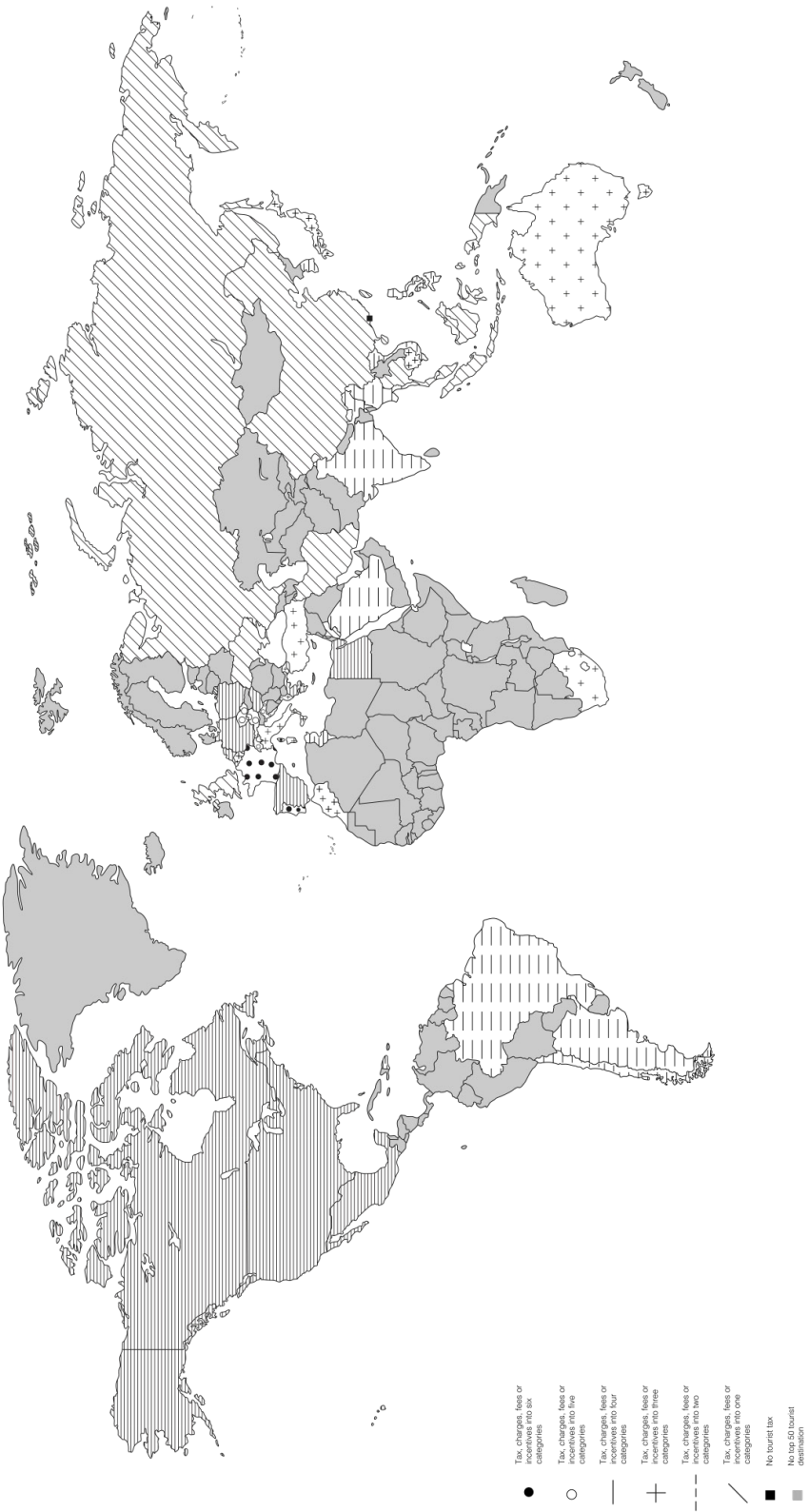

Source: Author's own creation. 
